\title{
Active Participation, Insignificant Gains: The Elusiveness of Gender Equality for African Women in the Liberal Global Economy
}

Paper Presented at the $4^{\text {th }}$ Women in Africa \& the African Diaspora (WAAD)

International Conference on Education, Gender \& Sustainable Development in the Age of Globalization

Shehu Musa Yar'Adua Center, Abuja, Nigeria

$3^{\text {rd }}-8^{\text {th }}$ August, 2009

Mojúbàolú Olúfúnké Okome, Ph.D.

Professor of Political Science

Brooklyn College, CUNY

3413 James Hall

Phone: (718) 951-5000, ext. 1742

fax: (718) 951-4833

email: mokome@brooklyn.cuny.edu

mojubaolu@gmail.com 
By the middle of the $20^{\text {th }}$ Century, following the groundbreaking work of Esther Boserup, feminist analysis began to acknowledge the active participation of African women in their countries' economic systems as producers. However, it was quite obvious, even to Boserup that while there was no doubt about women's participation, historically the gains from trade devolve disproportionately to men, a problem compounded by the fact that the institutions that manage the trading system locally, nationally, regionally and globally are dominated by men.

Unfortunately, contemporary awareness that the gains from trade are uneven has not yielded the transformation of the global political economy such that the observed disparities are corrected. These disparities have extraordinary distributional consequences for gender equality, since they stimulate differential responses between economic sectors, producers, regions in national and international economic systems, between advanced industrial and post industrial developed countries as compared with the predominantly agrarian, nonindustrial, developing nations, or the Northern and Southern hemispheres, as well as between and within African countries.

Advancements in trade and the profitability therefrom have generated prodigious amounts of wealth. Invariably, some of the gainers from trade are women. But even as some women gain from trade, most others suffer and are excluded from the benefits of trade. Given that the world has also widely acknowledged that there is a need to promote gender equity and equality, and many international instruments attest to this commitment, why are 
the disparities in gains from trade in the global economic system still heavily weighted in favor of men as compared with women? Facilitating equitable and equal gains from trade not only contributes to actualizing stated commitments to end all forms of discrimination against women, the goals of the Beijing Declaration and Platform of Action, and the achievement of the Millennium Development Goals, it also devolves positively to the enhancement of human well-being. Given that African countries have affirmed their commitment to these various international instruments and purport to be seized of the necessity of achieving gender equality, concrete gains in gender equality in trade would more demonstrably underline their commitment. With a focus on: The Multilateral Trading System and WTO Agreements; Economic Partnership Agreements (EPAs) and their impacts on African Women; and Regional Trade Agreements (RTAs): Lessons Learned from RECs (and possibly SROs), this paper will consider post 1945 African political economy, examine the continued parlous gains made by African women and attempt to explain the domestic and international causes and consequences of their marginalization. It will also suggest some remedies.

\section{Introduction}

"The issue of inequality relates centrally to the disputes over globalisation. A crucial question concerns the sharing of the potential gains from globalisation, between rich and poor countries, and between different groups within a country" Amartya Sen (Anh-Nga TRAN-NGUYEN and Americo BEVIGLIA ZAMPETTI 2004).

1. Debate and Argument: Feminist Analysis on the implications of Gender and Trade for African Women. The Multilateral Trading System and WTO Agreements 
The mainstream discourse on the multilateral trading system is that a liberal or open trade system benefits all. To the contrary, the feminist critique of the global trade system insists that women may remain marginalized in the global trade system even as economic growth occurs. They therefore campaign for inclusive globalization, also known as globalization with a human face, or what the International Labor Organization (ILO) describes as "globalization which puts people first; which respects human dignity and equal worth of every human being" (ILO n.d.; WWG on FfD, 2009). However, globalization with a human face remains elusive, and due to the effects of the power disparities within the system, seems to be an unlikely prospect under the current global system, where Africa was incorporated as a supplier of agricultural commodities. Lately, the continent has also been a source of undocumented migrants and informal, small scale trade in small-volume manufactured commodities that are often smuggled across state borders.

Given the antinomies of the global trade system, it stands to reason that the gains from trade would accrue differentially by economic sector, national or international region, gender, class and status. Thus, while some women benefit from trade by virtue of their ability to compete more equitably, and the provision of more opportunities within the trade system, there are even more instances of women who have suffered devastating losses and declines under the liberal trade regime. Poor women are more drastically affected, and Africa has a very high percentage of women who have been "left behind" in the calculus. For example, while low level manufacturing jobs, service economy employment and work in the agricultural sector are open to women, in all these sectors, majority of the downtrodden 
tend to be women. Increased competition by manufacturers, service sector businesses, and agribusiness is accompanied by the proliferation of low wage, low-to-no-benefit jobs and consequent marginalization under the regime of trade liberalization. African women have the fewest of these jobs because the promise that adjustment to the global economy would yield increased foreign direct investment has proved elusive. For a while, as a result of the restrictions placed by the Multifibre Agreement on Asian textiles imports and the simultaneous into developing countries, Asian textile manufacturers flooded into various African countries, hiring both men and women as low-wage, no-benefit casual/day laborers.

While employment in the textiles factories meant that some women were able to gain a toehold in the formal economy, make modest financial gains by saving as much as they could from their modest wages, and escape from some elements of family-imposed patriarchy, the end of the Multifibre Agreement short-circuited whatever modest gains were possible when most of the textile manufacturers pulled up and left, some overnight, and owing wages to their workers. Given the current global economic meltdown, the last hired, first fired maxim would probably imply that women lose even their feeble toeholds in the markets. Their continued lack of access to, and control over capital, including land, labor and finance means that their interests are not prioritized in trade talks and regulations.

To underscore the importance of gender in these processes, Peggy Antrobus, the first General Coordinator of DAWN clearly explains why we should pay attention to the gendered consequences of trade: 
Trade policies have different consequences for women and men because women and men differ in their access to economic resources, their social responsibilities, and in their biological make up. Thus, trade policy impacts on the economic, social, cultural and political welfare of both men and women in particular ways that concern each (Antrobus n.d.).

Radical critics of globalization and the trade system from the developing countries make a similar critique to that by feminists. They point to the inequities in the trade system that tips the balance in favor of developed countries, and against the developing countries and call for a revolutionary overhaul of the global trade regime. The Third World Network (TWN) is one of the most active clearinghouses of the critiques. The TWN contends that trade inequities are to be found in virtually all negotiations in the global trade system, causing the operation of an unequal rate of exchange in negotiations on both trade and nontrade issues. This is due to the structural power of the developed countries as compared with their developing counterparts. Consequently, all rounds of negotiations, whether it is the Uruguay Round under the General Agreement on Trade and Tariffs (GATT), or the Doha Talks within the WTO regime, favored the interests of the developed countries for trade both in agricultural and industrial goods. It is a mark of the power disparity between developed and developing countries that the former often lectured the latter, insisted on setting the agenda, and on prioritizing their concerns, to the disadvantage of the latter.

Developing countries have become increasingly organized over the course of the GATT and the WTO negotiations; the structural power of advanced countries in the global 
trade system and the historical advantages they gain thereby ensures that they remain more influential in directing the course and outputs of trade talks. Conversely, since the rules of the game do not favor Africa, it is also clear that to the extent that the current regime remains in place, African interests will neither have priority nor will they be respected. This is because Africa has no power in the management and design of the system. It is extraordinarily important to realize that trade negotiations and rules are technical, but their impacts and consequences are costly in human terms for the peoples of developing countries, particularly African women because they have few safety nets, and may already be disadvantaged in their national and household economies.

As a result of the dependence on international trade, in many developing countries, food security is challenged, export revenues fluctuate wildly, local commodities producers may be driven out of the market due to challenges from cheaper imports, farmers may even be forced to despair when they are unable to afford to either secure or service loans, or even access water, as seen in India (Deshpande 2002; Stone 2002; Shiva et al., 2000) and China (MacLeod 2001), where more and more are committing suicide. While Western countries have acknowledged that food security is a problem, and have supported the use of humanitarian aid as a solution, humanitarian aid cannot completely resolve the problems, particularly in light of the fact that according to the UN, over one billion people worldwide are currently hungry, and the numbers are expected to rise. An indicator of this situation is that in 2008, there were food riots in over 30 countries, and the governments (including commodities exporters like India and Argentina), seeking to protect their people, were 
pressed to prohibit food exports. In Africa, Egypt and Zimbabwe are among those who experienced food crises.

The Obama administration's Secretary for Agriculture, Tom Vilsack was right in his assessment of the problem of food insecurity but wrong in his endorsement of the use of genetically modified organisms (GMO), among other scientific methods in agriculture, as a response to the world food crisis. If Vilsack is right about food shortages in the following statement: "I can figure out there are only three things that could happen if people do not have enough food people could riot, that they have done; people migrate to places where there is food, which creates additional challenges; or people die," and the G8 is leading the development of a global consensus on the need for increased global food production, particularly in the developing countries, and they're aware that there's a shortfall in meeting the recommended UN goal of reducing by $50 \%$, the number of people affected by chronic hunger by 2015, and they are aware of the "alarming data" on malnutrition (over 1 billion hungry), and there is also awareness of the connections between high food prices, relentless economic crisis, climate change, it is puzzling to observe that in the short term, no money is forthcoming to solve the problems. Instead, the G8 communiqué correctly identified what ought to be done but only offered platitudes when it came to offering conclusions. The communiqué said:

More should be done to increase the quantity and enhance the quality of agricultural production and enable all citizens to have economic and physical access to safe and nutritious food... structural factors may underpin [higher 
food] prices over the medium term and ... increased volatility and demand raise important questions about food security for the future (Blas 2009). The G8 followed this wonderful analysis with a preliminary accord to demand that international trade and markets are "well-functioning" in order to enhance food security. The moral of the story is that platitudes abound but concrete actions to solve the problems are non-existent. The discussions among the powerful have neither consulted with experts from developing countries nor do they take the developing countries' NGOs, some of which have consistently made the same claims seriously. Another lesson from the G8 discussions is that Africa has to be proactive in developing its own responses to inequitable trade, and to prioritize gender and trade in context specific ways.

Food security has even graver consequences. Developing countries' balance of payments also suffers when they are dependent on food imports and food prices escalate. Further, TNCs are better equipped to succeed than domestic food producers, and the dominant TNCs can, and do force lower prices on weaker parties. In developing countries, increased differentiation and segmentation occurs that privileges those producing for exports, who also have political clout, credit, reliable access to inputs (water, land, labor, state support), while those producing for domestic consumption may lack all or most of the factors identified and become increasingly impoverished and marginalized. The dependence on international trade and the long distance trade required could also negatively impact on ecology and climate, well-being and nutrition (Third World Network 2008). 
There are also significant human rights implications. Developed countries' power is expressed in the form of their ability to threaten and use economic sanctions, which means that developing countries often favor the compliance with WTO rules over respect for their citizens' human rights. The threatened rights include the right to food, to open and participatory consultations (including inquiries and public hearings by national legislatures, as well as complaints by peasant organizations, and commodities traders' organizations. In the short term, the objective should be efforts by governments to develop national mechanisms and strategies that develop food production and supply systems with an awareness of, and responsiveness to the WTO process while also being highly conscious of people's needs. Governments from developing countries will also be armed with information and data that could support them in their bilateral and multilateral negotiations. The problems faced by developing countries include the conflict between bilateral and multilateral agreements such that more favorable multilateral rules, for example, on tariffs, cannot be applied because more restrictive bilateral free trade agreements are signed (Third World Network 2008). States then have the responsibility of protecting their citizens from undue draconian measures from the global trade system.

Developing countries have the benefit of the principle of special and preferential treatment, which affords them the ability to take measures to protect domestic markets from wild swings caused by the vagaries of global markets. However, most developing countries do not take advantage of this principle. One of the remarkable effects of trade liberalization is that while only about $15 \%$ of the world's food is traded internationally, the prices of these 
foods influence domestic prices such that there is a convergence in domestic and international prices. Given the stark economic realities faced by their people, one of the ways in which developing countries could take advantage of the principle of special and preferential treatment is to consult widely and inquire into the extent to which they are food secure, as well as consider the human rights implications of their trade negotiations. Then, guided by their findings, they can support, protect and extend human rights using some of the prescriptions of the UN Special Rapporteur on the Right to Food, Prof, De Schutter (Third World Network 2008). These recommendations can be found in the conclusion. Given experiences thus far, it remains highly unlikely that developing countries would take advantage of this principle.

It is important to understand and underscore the importance of gender to the determination of unequal gains from trade. Thus, the impact of gender on differential gains by country, sector and international system is worthy of attention. It has been documented that female workers are preferred in labor-intensive industries that desire cheap and flexible labor, and believe that women's "nimble fingers" and the dexterity therefrom yields increased productivity. Women are also believed to be more docile and easier to control. It is also documented that there are lower barriers to entrance into labor-intensive industries, vicious competition for marginal gains, and therefore, a tendency to race to the bottom, due to the desire to cut the cost of production. Further, it is documented that Africa, like many developing regions, has large pools of cheap labor, and the adoption of neoliberal policies of structural adjustment throws low-skilled women into the labor market, and further swells 
the numbers of available workers, as well as the elasticity of labor. In consequence, the race to the bottom pushes wages down and keeps them low. Thus, Africa's experience has been that while the volume of exports produced using labor-intensive methods are amplified, the terms of trade of those exports, compared with high technology exports, decline. Increased trade therefore does not necessarily contribute to reducing gender inequality. At the same time, it is impossible to make categorical statements on the gains from trade. For some women, income is redistributed within the household, and their status is improved, but even for these women, there are persistent gender inequalities, experienced in lower wages for women as compared with men, job segregation (women being confined to low-status jobs), and inadequate provision of basic social services like health and education to women Conditions of work also worsen for women because of the greater flexibility of working arrangements in the sectors that hire them in large numbers.

In economic sectors like agriculture, textiles and clothing production and services, despite the expansion of markets, and good chances that incomes might be boosted, if imports cause declines in areas of domestic production that are dependent on women's labor, there is a need for corrective measures that demand significant investments to enhance women's skills, as well as support them to find ways in which they can become re-absorbed into the economy. In many African countries, there are few-to-no resources available to handle challenges faced by women and solve their problems. It is an enduring colonial legacy that many African countries also do not have the luxury of considering switching 
from one economic sector to another, thus, they are hamstrung by the constraints from monoculture or mono-export economies.

Multilateral trade rules do not favor African countries due to their relative weakness vis a vis other countries in the world economy, and the assumptions that trade would generate benefits has not been borne out by experience. Moreover, the observation of existing norms in the international trade system does not allow for African countries to pursue gender equality policies and procedures. Thus, Africa suffers negative consequences from multilateral trade agreements within the domain of the World Trade Organization that in turn negatively impact on gender equality.

Multiple international instruments (to which African states are signatories) assert that gender equality is a fundamental human right and that government policies ought to be directed at advancing sustainable human development. This is due to the assumption that participation in international trade could yield both profits as well as disabilities. As mentioned above, historically, massive distributional gains have accrued from involvement in trade, but those gains have not been evenly enjoyed. Africa as a continent has often been left holding the short end of the stick because its gains have been more meager and fleeting than most. The gains have tended to go to the producers of manufactured goods, and in more recent times, the producers of information technology. Until the global economic meltdown created generalized skepticism about involvement in trade being a win-win situation, the enlightened self interest of the gainers implied that they found it desirable to 
attend to the question of equity in access to the proceeds of trade, if only to ensure the quietude and acquiescence of the impoverished majority.

Until just recently, the focus within the liberal establishment has been to recommend "Capacity building for policy-makers, as well as the use of specific analytical tools designed to assess gender-specific trade impacts" as crucial in trade negotiations. Capacity building is also suggested for women traders, so that they can access the gains from international trade. The innovative contributions from information and communication technologies have been suggested as tools that could facilitate women's ability to compete. The recommended reforms are inclusive of the private sector and civil society, with advocacy of respect for gender equality in the workplace. To this end, the mechanisms and strategies utilized by multinational and transnational corporations to encourage and foster gender equality in their production systems and those of their sub-contractors, and the strategies used by civil society organizations are useful sources of solutions. These initiatives include fair trade, socially conscious investment, and gender equality particularly as it applies to trading opportunities for women. Given the great need in the African continent, there are grounds for a special focus on the continent's poor, including the women.

\section{African Women's Active Participation and Insignificant Gains-Evidence}

\footnotetext{
"The completion of the Uruguay Round of trade talks at the GATT, and the establishment of the World Trade Organisation on January I 1995, has drawn all domestic issues into the 'global economy', and all matters related to life, ethics, values, ecology, food, culture, knowledge and democracy - into the global arena as 'matters of international trade'. The perspectives and position of women in the remotest villages of the Third World have
} 
thus come into direct collision with the perspectives and power of men who control global patriarchal institutions." Vandana Shiva (Shiva n.d.)

This section of the paper draws deeply from Vandana Shiva's work as well as my past work on globalization, gender and trade in Africa. Shiva's work is valuable because when one plumbs the vein of her analysis on "home" and "ecology" it is possible to see the linkage between what happens in the west where reproductive racialized inequalities are used as the rationale for "home" building, and what happens in Africa with the Structural Adjustment Programs in domestic policymaking and GATT in the past, as well as the WTO at present (in the international system), such that African women's gains from trade are meager. Shiva's work is also useful for a critique of neoliberalism worldwide. For example, in many parts of the US, including the Pioneer Valley of New England region, organic farmers, $40 \%$ of whom are women, by simply following the norms, quickly get into increased levels of debt in an effort to expand. Many end up bankrupt and lose their farms. This is similar to the experiences in China and India, where small scale peasant farmers continue to commit suicide because they are unable to service their loans. The irony is that in both cases, the farmers' attempt to succeed is what causes failure. They often are encouraged by success in production to acquire more land, using bank loans. Inability to meet their debt repayment obligation, too-rapid and unsustainable expansion of their landholding, and overproduction of commodities, which causes reduction in prices, further complicating farmers' ability to repay debts. It is also important to understand the feminist perspective on gender relations. Crucial to this effort is the need to open up the ways in which the Western feminist 
perspective is rooted in gendered welfare state projects that construct what Klein describes as the "fortress continent" that keeps out immigrants fleeing from impoverished economies.

According to Vandana Shiva, the inception of a new order of globalization signaled by the end of the Doha round of the GATT and the final agreement that established the WTO, also mark "a new era of gender politics" where gender analysis must acknowledge a paradigm shift from focus on domestic to global political economy because globalization entails the removal of national barriers to trade and investment. Thus, gender relations between global actors must be explicated. As well, gender analysis must abandon "the impact and victimhood paradigm" in favor of "a structural and transformative paradigm." Essentially, mainstream gender analysis focuses primarily on the effects of the global economy on women, and this obscures the reality, which is that:

global financial, trade and corporate institutions have differential impact on men and women, rich and poor because they are institutions dominated and controlled by men, especially men from the rich G-7 countries; and being shaped by a particular gender, class and race of humans, they are expressions and vehicles of the preferred visions, aspirations and assumptions of this particular group (Shiva n.d.).

Instead of a focus on the impact of globalization on women, it is important to consider the patriarchal basis of paradigms, processes, policies and projects of global economic structures... how women's concerns, priorities and perceptions are excluded, how the economy is defined and how economic problems and 
solutions are proposed and implemented. Ecology, economics and gender are all thus intimately related to the construction of 'home' as a metaphor (Shiva n.d.)

for both economics and ecology, and a there was a seamless relationship between production for subsistence and production for exchange. With the emergence of capitalism, the paradigmatic shift that occurred made a distinction between the household economy and capitalist production in factories. In terms of gender, this contributed to the patriarchal devaluation of work done by women as part of a household economy, and the diminished importance of subsistence economies.

The ascendancy of capitalism bore with it, the predominance of market economic value, and control of the management of the economy by capitalist patriarchs who do not believe that economic production for ecological and human survival is important. As Vandana sees it, this means 'the domain of nature's economy, and the domain of the sustenance economy' are ignored, and by implication, production that foregrounds "the protection of the earth's life and human life" (Shiva) are construed to be of peripheral importance, while "cash or market price" and profits are considered primary and crucial. This amounts to the exclusion of women's work and domestic production from the formal economy. Instead, the valorization of formal economy-derived earnings and contributions to the growth of the Gross National Product marginalize women and the environment in the calculus of development indicators. This means in the first place that nature (the environment) and women (domestic production) are rendered invisible as possible sources of 
generating the development of the market economy. Essentially, the market-driven capitalist system then ignores the greater part of the world and its contributions. By implication, the deleterious consequences of the capitalist economy for these populations are ignored, disregarded and considered insignificant, thus increasing the likelihood and depth of immiseration. These effects are felt worldwide, but in the African continent, depth and breadth of the inequalities fostered by the uneven gains from participating in the global economy are more extreme. Ecological destruction and degradation create tremendous problems for the poor, but women suffer more, even as GNP grows and global trade increases and prodigious amounts of wealth are generated. Under such conditions, it was quite common to find that there was a great degree of concentration of wealth, simultaneously experienced with drastic reductions in welfare and assistance to poor and marginal populations. Shiva also argues that there has been maldevelopment, experienced as the wholesale devaluation of the probability that nature and women can "produce life, goods and services for basic needs... Women are devalued, first, because their work co-operates with nature's processes, and second, because work that satisfies needs and ensures sustenance is devalued in general. “

Distorted development/maldevelopment and the growth it generates create an antipeople economy where there is less nurturing of life and life support systems. Nature's economy (through which environmental regeneration takes place) and the people's sustenance economy (within which women produce the sustenance for society through 
'invisible' unpaid work called non- work) are being systematically destroyed to create growth in the 'global market economy' (Shiva n.d.).

In drastic contradistinction to maldevelopment, there is the people's economy, also conceived as the free economy, and defined as the foundation of the economy and society, which is "non-monetary, unpaid work for one's own and family needs, community activities, mutual help and co-operation within the neighbourhood" (Shiva). Unlike this free economy, there is what Shiva describes as "the protected sector which consists of production, protected and guided by official means for domestic markets; food, constructions, services, administration, health, schools and culture." Following Pietila, Shiva argues that "the 'freetrade' economy (is) the fettered economy". This economy, which is the same as the liberal economic system is constituted from the worldwide import-export trade. From 1945, the rules that govern the global trade system have been generated by processes controlled by the Bretton Woods system that produced GATT, and later the World Trade Organization. In this liberal economic system, the market was constructed as supreme, and construed as a selfequilibrating system where free trade and the competition it generates produces efficient production and ever-increasing gains in trade. However, Shiva correctly points out that "dependency, vulnerability, and compulsive competitiveness" are also an integral part of the system. These latter tendencies are more obvious in poor countries and become manifest in the affluent countries in hard times. Shiva gives the following example: "in 1980, the proportions of time and money value that went into running the informal or free economy were $54 \%$ and $35 \%$ respectively. The time and money value in the protected sector was $36 \%$ 
and $46 \%$ respectively while that in the 'fettered economy 'was 10\% and 19\% respectively. In patriarchal economies, the protected and fettered economies are perceived as the primary economy, and the informal economy as the secondary economy."

Following Marilyn Waring (1988), Shiva explains that the free economy (focused on women and nature) is not reckoned in calculus of national accounts, GNP and GDP. It is inevitable that the 'fettered' economy (Focused on production as part of the GNP, national accounts and GDP) would go through downturns that produce deficits, and free economy (women and nature-dependent) has to bear the brunt of ensuring the survival of families upon whom economic crisis and harsh neoliberal economic policies weigh most heavily. When neoliberal policies of structural adjustment and austerity programmes are imposed, and there are budget cuts, the poor suffer more than any other social group. Structural Adjustment Programmes (SAPs) offer only economic pain for the poor; because they lose whatever social safety nets they had before the inception of the programmes. For Shiva, there has been a paradigm change from considering "home" as important to making "trade central. The consequent effect on economic value has been to propel a change in the meaning of value from "worth" to something determined by exchange and trade. "Home" as the root and metaphor for the economy was substituted by trade as a metaphor for the economy and as a source of economic value. The trade metaphor for the economy has also rendered nature's economy valueless. Thus both the marginalisation of women's work and nature's work are linked to 
how the metaphor of 'home' was reconstituted as the domain where no economic value is produced (Shiva n.d.).

Central to Shiva's analysis is the tragedy entailed in the changes in the meaning of women's positions in relation to the household and family. The development of capitalism and ascendancy of neoliberalism have had differential effects on different parts of the world. In the west, as a result of the operation of the concept of embedded liberalism, the welfare state developed in response to struggles by labor and the poor for more and better rights, while in developing countries, imperialistic and colonial exploitation allowed the development of predatory states that preyed on the people. Unfortunately, the rise of political liberalization has only led to the emergence of illiberal democracies in many parts of the developing world, including Africa. With the absence of concern for the welfare of citizens, even during serious economic crises, people are left to fend for themselves and gender relations and women's roles remain stunted.

In Africa, both the nuclear and extended family are part of women's work space/domain. Although people tend to make a dichotomy between traditional and modern conceptions and institutions in the family and society at large, such dichotomies don't exist in fact, and there is a spectrum of combinations, adoptions, rejections and re-emergence of old practices in new forms. The phenomenon of globalization has always affected the choices that people make, and while in the West, a welfare-state subsidized model of gender and women's roles emerged due to the operation of the concept of embedded liberalism, the African state has been predatory and disinterested in people's welfare. 
The economic crisis also has ecological consequences since it causes depletion of natural resources, not just because poor people intensify their exploitation of natural resources but because the principle that indebted countries should concentrate on their comparative advantage means that exploitation of natural resources by transnational agribusiness and mining interests is encouraged as a solution to the economic crisis. Depletion, degradation and destruction of the environment either ensue or intensify. The entire society suffers but to the extent that poor women have been structurally marginalized, being squeezed by economic crises also means that they would have to increase the effort at generating income. This has been known to affect flora and fauna. The search for fuelwood for example causes the depletion of forest resources. The search for food could challenge the preservation of endangered species. Essentially, people are pitted against the environment instead of existing in harmony with it and acting in ways that are committed to ensure its constant regeneration. Considered as a historical process, the rise of the industrial revolution also meant the rise of a perspective that separated industrial production from production for consumption/subsistence. The insistence that only the former constitutes value, and only its commercial exploitation by humans generates value means for Shiva that: "Nature, whose real nature it is to rise again, was transformed by this western worldview into dead and manipulable matter. Its capacity to renew and grow had been denied.” As Shiva sees it, the reciprocity between humanity and the environment is consequently threatened, challenged, or lost. 
The application of neoliberal economic principles to the area of Intellectual Property Rights in the global trading system was shaped by the World Trade Organization's (WTO) Trade Related Intellectual Property Rights Agreement, which incorporated and co-opted the domain of ideas, knowledge and innovation. As a consequence, the rights of the poor, particularly in developing countries, and most obviously in the case of indigenous people, have been violated. Through the hegemonic practices of the WTO (as a representative of the transnational production and commercial interests in the most powerful countries) the Intellectual Property Rights (IPRs) of poor and indigenous people have been quietly and "legally" appropriated. According to Shiva, both women's and nature's creativity are thereby appropriated, distorted, subverted and rendered invisible as well as irrelevant. The global commons are subjected to patriarchally determined/controlled and distorted enclosures where the sustenance of life through regeneration is categorized as repetitive, while the destruction of the environment to feed industrial production is valorized as creative. The TRIPs agreement enables the patenting of inventions and procedures. It also allows the holding of patents on indigenous people's oral traditions, knowledge systems, and even their DNA. It allows patents on "plant varieties, covering ownership of traits and characteristics." It also formalizes a process where indigenous people must prove that TNCs are appropriating their bodies and the information they carry their knowledge systems, flora, fauna, etc. in what amounts to piracy and appropriation without any acknowledgment and consciousness of gross disparities in power. By implication, TNCs gain economic rights and exclusive trading rights in a manner that recalls imperialistic acts of the past. When filing for patents 
in developing countries, the TNCs have the additional privilege of low sunk costs, privileged high level access, and benefits deriving from economies of scale. To the contrary, scientists and firms from developing countries have to spend huge amounts of their resources to file patent applications in developed countries. Such costs are prohibitive enough to ensure that patent applications are not pursued with the same amount of vigor. In addition, since the sciences are still dominated by men, and most of the heads of TNCs are male, women are extraordinarily marginalized in the process (Corpuz 1995).

The impact of TRIPs is not to be underestimated. Patenting and scientific power are determined by the way in which the G8 controls scientific processes and research and the science rooted in indigenous practices is kept out of mainstream or "Western" Scientific Discourse, which tangibly excludes (and also appropriates) local scientific knowledge. According to Frederick Grinnell, the impact of neoliberalism causes a shift from a "publish or perish" model to a "patent and prosper" model. This undermines even the imperialist mythology of scientific knowledge as rooted in practices excluded from the market. Thus, there is a "hand in glove" relationship between scientific knowledge and extractive market practices that operates to the detriment of the interests of the poor (Grinnell 2008). African women and indigenous people, whose knowledge is appropriated and patented, have complained in international, mostly UN-sponsored fora, demanding more equitable rules, but such rules are yet to emerge. 
Incongruity of active participation and insignificant gains: A rights-based argument

Up until the moment of the recent meltdown of the global economic system, neoliberalism reigned supreme in the contemporary global system. Even during its period of ascendancy, feminist critics contend that the worldwide feminist movement may have become the captive of the neoliberalist ideology. Thus, it is observed that many of the old gains made by the feminist movement have been eroded because the corporate elements of old feminist movements that generated inclusionary politics have been swept away. In order to foster the development of new supports for feminist struggles to advance the cause of marginalized women, therefore, feminists, and other movements for the downward redistribution of wealth, must develop their capacity to proactively respond to the new challenges in creative ways (Duggan, 2004). More critiques of neoliberalism come from scholars, some of whom identify themselves as feminists, while others reject the feminist moniker. For the Africans among these, Western imperialism in the world's political economy is mimicked by that in the academe, and in social relations. Thus, there exists a presumption of Western feminist superiority and its capacity to lead the worldwide feminist movement, which is not borne out by historical fact (Steady, 2002; Okome, 2003, 2005).

Socialist feminists contend that the presumed benefits of globalization do not extend to African and other third-world women. For African women, this is very serious business. While the politics of inclusion produced the heady idealism of a united front of all women 
against the marginalization and oppression of patriarchy, the promise of unity in the face of adversity never materialized; there was a hierarchy that privileged Western women who were the controllers or conduits of funding, the published scholars whose ideas were widely disseminated worldwide, the advisors that recommended and prescribed solutions to women in other regions of the world, the dominant voice at international conferences, workshops and negotiations to whose advantage the mobilization of bias worked, since they were able to set the agenda to which women from other parts of the world respond (Okome 2005).

The problem did not begin with this latest manifestation of globalization. It was also present in the pre-1985 period when the progressive forces in the development field talked excitedly about, and campaigned vigorously for, the adoption of the New International Economic Order. The problem with the most recent incarnation of globalization is that it acts in a catalytic manner that intensifies old tensions, and produces new challenges. Although the neoliberal proponents of globalization argue that the phenomenon presents numerous possibilities of benefits to humanity, and although one can clearly see how advances in communications technology have made the world smaller, the advantages are not enjoyed equally by all people. While most have control over, and access to the latest technology,

Others do not have the means to purchase such technology. While technological advances have eased a lot of the tedium of modern life, they are responsible for a myriad of problems that affect the environment, and consequently, the health and well being of the 
consumers of technology and the labor that produces technological goods, sometimes without the financial ability to purchase and use such technology (Okome 2005).

Indeed most African women feel the challenges of globalization in a myriad of ways. In most African countries, the idea of the welfare state is non-existent. People must fend for themselves from birth to death, with the largesse or benevolence of the extended family as the only cushion against the vagaries of an uncertain world. For these women, globalization has caused tremendous dislocations, since the opportunities that exist for them to participate are often as low paid overworked, no-benefit labor. Some neoliberal economists contend that any job is better than no job, and that it matters little what jobs pay, as long as one is employed. However, this is often the argument of those that feel like veritable masters of the universe, who know that no such adversity can possibly be visited upon them. For those that have access to only the most menial jobs, having no choice does not mean wanting nothing better (Okome 2005).

Globalization has also broadened the spectrum in terms of locale of employment. Those African women who are participants in the labor market could either work at home, in their country of origin, but given the dearth of foreign direct investment in most African countries, participation in the global job markets where there is better pay and better conditions of service is increasingly only available abroad. Regardless of geographical location, many African women must begin at the lowest rungs and claw their way up to some semblance of regular, decent employment. When they migrate or emigrate to seek employment, working-class African women find that the jobs that are most easily available 
are those that entail child- or eldercare (or care of the sick as home-health aides), cleaning jobs or piece work in sweatshops. Other African women are highly qualified white and pinkcollar professionals. When they are nurses, medical doctors, pharmacists, attorneys, university professors and the like, they are able to take jobs that are commensurate with their professional training. However, when they emigrate or migrate in search of employment, or they seek a more stable political, economic and social system, many of them often begin their first few years in the labor market by doing the same menial jobs as their less educated sisters. They only have access to the better paying jobs if they have skills that are in short supply in the country of settlement, and were recruited from their home countries with guarantees that these jobs are waiting for them. Even in these circumstances, immigrant African women are still subjected to manipulation, coercion and even extortion by some fraudulent recruitment agencies and employers who underpay them and fail to fulfill the terms of their contract (Okome 2005).

Specifically relating to agriculture, which is the sector within which most African women operate, according to Shiva, the TRIPs agreement is a violation of the human rights of farmers and people by granting unhindered dominance to TNCs in the critical areas of health and agriculture. For her then, TRIPs do not apply exclusively to trade, but is actually at its core, an indication of the moral values applied in dealing with other species, and with the powerless, minorities, use, control and protection of biodiversity by local communities who have as opposed to TNCs and their novel exploitative, and possessive drive toward enclosure. The hegemonic control of WTO derived legal system by the developed 
countries means that other ways of conceptualizing ownership that are grounded in alternative conceptions of moral and ethical values are marginalized, ignored, and rendered invisible. This challenges national autonomy and sovereignty and have tremendous social, economic and political consequences because TRIPs makes all life potentially the property of TNCs. Although the TRIPs agreement seems to exclude plants and animals from being patented when it states that: 'plants and animals other than microorganisms' cannot be patented, it allows for parts of animals and plants, as well as modified plants and animals to be patented. Also, micro organisms can be patented, and some have complained that this means all life can potentially be patented. Biodiversity and the role of poor women and poor farmers in ensuring its maintenance through their role as custodians of seeds are threatened. Within developing countries, a similar process is being promoted: to put pressure on governments to legalize the monopoly ownership of seeds, thus invalidating the poor, allowing TNCs and other monopolies to benefit from what was previously free knowledge.

The operation of the TRIPS agreement takes the power, control, and sovereignty over natural resources located in their territories away from indigenous people, and gives them to TNCs and other firms as monopoly rights. These monopoly rights yield monopoly profits. Developing countries are then in the peculiar situation of being the source of the most complex array of biodiversity but they are losing the ability to profit from what belongs to them. TNCs have appropriated these resources, knowledge, etc. without paying market prices that factor in what they stand to gain from the exploitation of the resources. The trade imbalance that results is also normalized when the sale of seeds acquired in these TRIPs- 
driven trading system go back to those from whom it was taken in the first place. This not only put money in the pockets of purveyors of seeds, but forces farmers in developing countries to purchase seeds. When things are carried to their logical conclusion, some farmers could be legally bound not to accumulate and utilize seeds because TNCs hold patents to them. In addition, when TNCs claim patents on the seeds and knowledge they gather from developing countries, they benefit from "centuries of innovation and selection by Third World farmers, especially women." They also violate the rights of farmers, which are accepted as valid by international organizations and contemporary laws. For example, the United Nations Food and Agriculture Organization (FAO) recognizes farmers' Rights; and the 1992 Biodiversity Convention produced at the Earth Summit, which requires that biodiversity conservation be given priority over IPR. These laws sometimes establish progressive rights but manifest what amounts to a backlash when those progressive terms are either modified to favor TNCs and their interests, or changed to reverse the gains they represent. A case in point is the International Convention of the Union for the Protection of New Varieties of Plants, which gave farmers the rights to save seed, but was amended in March 1991 to introduce a clause that farmers may have to pay royalties if produce and keep seeds for crops that they plant that are patented by TNCs and agribusiness. If this happens, food security and the well being of rural as well as poor and marginal populations will suffer and the debt crisis would worsen. 


\section{Conclusion: Gender, trade and development in Africa: Recap on Problems and}

Some suggestions on gender responsive trade policies.

The issue is not whether to have global trade rules, but rather what kind of rules, in whose interest do they operate and how they should be balanced to ensure that they do not have adverse impacts on social, health and environmental spheres nor worsen existing inequities. Peggy Antrobus, DAWN

The post Second World War international system is founded on liberal economic principles. In the development arena, poverty reduction has been a central concern. The liberal rationale is that free trade should generate gains from which all benefit. However, conventional wisdom has demonstrated that gains from trade are not equitably distributed. Lately, due to the insistence of women's rights activists, the gendered nature of the gains from trade has attracted increased scrutiny. Such scrutiny is especially important today, given the rocky nature of the global economic system. For African women, it is often suggested that access to better education, equal opportunities in the labor market, which in Africa, is predominantly agricultural, better property rights, expressed directly through changes in land tenure institutions to benefit women, and the reduction and/or elimination of gender based constraints to women's participation in production and trade would create better opportunities for women. Given that the fundamental bases of these assumptions are being challenged, it is even more imperative that the gendered nature of trade should be subjected to detailed inquiry. The objective of such inquiry should be not only to create a more level playing field for women, but to increase human welfare and engender genuine development.

More importantly, the rules of the game in the global trade system are not fair to Africans. These rules must be modified in some respects and radically changed in others. 
Since Africa is predominantly poor, it has very little power to force change. However, civil society organizations can play a crucial part in struggling for change. Women's organizations can play a crucial part in this effort. International organizations that are interested in equitybased claims for development should lend a hand by sponsoring workshops such as this, research efforts, publications, including position papers that suggest alternative courses of actions that might help pull the continent out of the doldrums. The hope is that by supporting gender-based responses to challenges in the global trade system, the entire society benefits to a greater degree than is possible at the moment. Whether we like it or not, African women are participating in a new global economy described by Naomi Klein (2003) as one where the division:

between fortress continents and locked-out continents. For locked-out continents, even their cheap labor isn't needed, and their countries are left to beg outside the gates for a half-decent price for wheat and bananas. Inside the fortress continents, a new social hierarchy has been engineered to reconcile the seemingly contradictory political priorities of the post-September 11 era. How do you have air-tight borders and still maintain access [to] cheap labor? How do you expand for trade, and still pander to the anti-immigrant vote? How do you stay open to business, and stay closed to people? Easy: First you expand the perimeter. Then you lock down.

According to the UN Special Rapporteur on the right to food, Prof, De Schutter, the rights based argument is a necessity, and the terms of trade should also be 
corrected/modified to reduce the inequities experienced by developing countries and their peoples. De Schutter made the following recommendations:

- Pending international agreements that address market and price volatility, developing countries need to protect domestic markets against sudden huge increases in imports. This implies the necessity of "orderly marketing schemes" such as those geared at organizing supplies

- It is unwise for developing countries exclusively or overwhelmingly depend on international trade as a means of developing food security. Domestic production is essential and policies that support peasant and small scale farmers should be adopted and promoted.

- The right to food is an essential part of ensuring food security. A stronger agricultural sector and empowerment of small scale farmers are essential elements of effective policy responses.

- The dichotomization of the agricultural system such that exporters are favored over those who produce for domestic production should be checked. In particulat, the current tendency to regulate the behavior of states and other TNC actors and enable the TNCs to operate unfettered is damaging. Strategies to address the resulting market distortions should be addressed using global governance mechanisms.

- Among the repertoire of possible mechanisms are:

○ In the short term, state recognition of their human rights responsibilities to their citizens, particularly in guaranteeing food security. To accomplish this objective, they ought to fearlessly regulate actors that operate in this area

- Medium to long term multilateral structure to better control all actors in the global trade system (Third World Network 2008).

It is also important to remember that fortresses can only exist if those enclosed within them

are complicit in their maintenance (Okome 2005). Unlike when Klein wrote the piece above, neoclassical economic principles are being challenged now by some of the fundamental tenets of their proponents: that markets are self-equilibrating and best left alone. Instead, the global meltdown reveals once again, the limits of the self-regulating market principle that undergirds liberal economic thought. Since this is a time of reexamination, those with critiques and alternatives are especially privileged to offer their 
ideas. They should not assume that such ideas would be taken at face value, but must be ready to struggle to demonstrate that a better world is possible.

According to Elizabeth King, "Gender disparities are very closely associated with poverty. The gap between men and women in such things as health and education is greater in poor countries than in rich countries, and within countries it is greater among the poor" (Mutume 2001). For Andrew Mason, "Societies that discriminate on the basis of gender pay a significant price in greater poverty, slower economic growth, weaker governance, and a lower quality of life" (Mutume 2001). The report: "Engendering Development Through Gender Equality in Rights, Resources and Voices", contended that if gender inequities are reduced, economic growth would be enhanced. Specific areas that ought to be addressed include:

- Granting women equal access to land, property and finance capital

- Constructing infrastructure that considers and meets the needs of women, particularly in the rural areas and urban slums. Access to water and fuel are crucial for women engaged in food processing and other economic pursuits

- Educational equity for men and women

- Engendering women's access to agricultural inputs, including training

- Reducing domestic violence to increase economic productivity, reduce absences from work, homelessness, medical problems and expenditure on police and judicial services

- Increased women's political participation

The kinds of markets and states that would tackle poverty and gender inequities as well as enhance women's rights have been suggested variously by women's rights activists.

For Noeleen Heyzer, the following measures are appropriate

- Women's access to, and control of markets where they are the dominant participants

- Women's access to economic assets, wage labor, equality at work 
- Women's increased struggle for political globalization-not only to devise rules to level the playing field, but to develop a development-friendly environment that foregrounds social elements of development. When this happens, there would be genuine inclusion of women, a realization that they do not have the same access to markets all over the world. The strategies should differ in places where women are socially restricted from open participation in markets and places where the constraints are about lack of capital and infrastructure.

- Increased women's access to technological innovations, particularly information technology

- Broaden the base of the women who benefit from globalization (highly educated, affluent, well-connected and having more capital as well as access to resources)

- Go beyond microeconomic solutions. It is a great breakthrough that microcredit has become ubiquitous, but there are problems that militate against women's ability to use microcredit. These include increased tension and potential of violence within families if men do not have similar access, possibility of women handing over loans to male relatives, particularly where they are exluded from free participation in markets due to being secluded.

- Struggle for stronger global civil society in which women's NGOs are a strong component

- Put rights into practice so that women can live their lives in dignity (Tsikata 1995; Sandrasagra 2000)).

According to Ramachandra Reddy of India in a statement to the United Nations General

Assembly's Social, Humanitarian and Cultural Committee on October 10, 2000,

Despite new initiatives and commitments, the sad reality is that the situation of the world's women is progressively deteriorating due to globalisation ...societies with the greatest gender equality had grown the fastest, and it must be recognized that gender equality is crucial to the development process. The link between gender equality and development means marginalisation of women must be stopped along with the continued feminization of poverty (Sandrasagra 2000).

The feminist perspective on gender relations is more progressive than the mainstream perspectives, and Western feminist perspective, although rooted in gendered welfare state projects that construct Klein's "fortress continent" ideals, can, and has been pushed to 
support third world women's interests. This can be seen in the UN process, with Beijing and its subsequent follow up discussions as indicators of much progress, but there is still much work to be done because there is such a disparity in the power of the actors in the debates and negotiations. One can also consider elements of the same process and model of neoliberal economics having a grave impact on farmers, including the women, due to a problematic strategy that pushes for unsustainable expansion, causes indebtedness, bankruptcy, and the death of the farms, or their acquisition by agribusiness, which may paradoxically, be able to produce cheaper food and enable poorer people to consume organic foods. In India and China, there are thousands of peasant farmers who have, and are being driven to suicide because they followed the neoliberal model and have unsustainable debts. It is a tragedy of massive proportions, but the world moves on and most are totally aware that this is happening, why it's happening, and the connection of what's happening there to everyday practices and experiences.

Finally, what does Africa want to gain from trade? How does it see women's interests in the trade system? Does it consider women's rights to be important? If so, how will it do this in international and domestic policy, and how will it implement the changes? In addition, to implement policies that enable Africans to gain from trade, there should be prior attention to whether it serves African interests to continue in the global trade system as it exists, whether the system would serve African interests to modify the system, and what kinds of modification are appropriate. This being done, how will Africa realize its objectives in this respect? The current global economic meltdown presents an ideal opportunity for 
Africans to participate in rethinking the reformation of he global economic system. Should

Africa think been in

\section{BIBLIOGRAPHY}

Africa, Caribbean and Pacific, Economic Commission for Africa, African Union. EPA

Negotiations: African Countries Continental Review. Review Report, Economic Commission for Africa: African Trade Policy Centre, 2007.

Akyuz, Yilmaz. Global Rules and Markets: Constraints over Policy Autonomy in Developing Countries. Series, Penang, Malaysia: Third World Network, 2007.

Antrobus, Peggy. "Women's Perspectives: Statement by Peggy Antrobus, DAWN (Development Alternatives of Women for a New Era) Caribbean ." Third World Network.

Barrientos, Stephanie, Catherine Dolan, and Anne Tollontire. Gender and Ethical Trade: A Mapping of the Issues in African Horticulture. DFID ESCOR Project, 2001.

Blas, Javier. "US Urges Food Output Boost to avert Unrest." Financial Times (Middle East), April 20, 2009: 4.

Coomson, Joseph. "Don't Sign the EPAs - Coalition Tells African Gov'ts." Ghanaian Chronicle, Accra, July 9, 2007.

Corpuz, Victoria Tauli. "Depoliticizing Gender in Beijing." Third World Resurgence, September/October 1995.

Das, Bhagirath Lal. "The WTO's Doha Negotiations: An Assessment." UNDP Regional Trade Workshop - Doha and Beyond: Incorporating Human Development into Trade Negotiations. Penang, Malaysia: UNDP Regional Centre in Colombo, UNDP Malaysia, Third World Network, 2007.

Deshpande, R. S. "Suicide by farmers in Karnataka: agrarian distress and possible alleviatory steps." Economic and Political Weekly, 2002.

"G-33 Non-Paper on Special Safeguard Mechanism ." 2007.

Gibb, Heather. Asia Pacific Trade and Investment Initiative. E-Discussion Paper, Colombo: UNDP Asia-Pacific Trade and Investment Initiative, 2007. 
Grinnell, Frederick. Everyday Practice of Science: Where Intuition and Passion meet Objectivity and Logic. New York: Oxford University Press, 2008.

ILO. ILO World Commission on the Social Dimension of Globalisation.

Khor, Martin. Analysis of the New WTO Agriculture NAMA Texts of 6 December 2008. Analysis of WTO Trade Negotiations, Third World Network, 2008.

-. "Bilateral and Regional Free Trade Agreements: Some Critical Elements in Development Implications." UNDP Regional Trade Workshop - Doha and Beyond: Incorporating Human Development into Trade Negotiations. Penang, Malaysia: UNDP, Third World Network, 2007.

Khor, Martin. Doha and Beyond: Incorporating Human Development into Trade Negotiation. Workshop, Penang, Malaysia: UNDP, 2007.

—. "Food Crisis, Climate Change and the Importance of Sustainable Agriculture." FAO Food Security Summit, Rome. 4 June 2008. Rome : Third World Network, 2008.

Khor, Martin. The Recent WTO Agriculture Negotiations: Domestic Report. Conference, Penang, Malaysia: UNDP Regional Trade Workshop, 2007.

Khor, Martin. The Unequal Exchange in the Doha Negotiations. Critique, Penang: Third World Network, 2007.

-. "The Unequal Exchange in the Doha Negotiations." Third World Network, December 17, 2007.

MacLeod, Calum. "Farmer's wives paying a terrible price for progress." Asia Times, November 8, 2001.

Makunike, Chido. "EPAs: Africa Should go Beyond Crying." The African Executive, 2009.

Mutume, Gumisai. "Gender Discrimination Not Good for Growth." Third World Network, March 7, 2001.

Okome, Mojúbàolú Olúfúnké. "African Women and Power: Labor, Gender and Feminism in the Age of Globalization." SAGE Race Relations Abstracts, 2005: 3-26. 
Randriamaro, Zo. "Gender, Trade Liberalisation and the Multilateral Trading System: Towards an African Perspective." CODESRIA Gender Institute - 2002 Session, Dakar, 1-6 July, 2002. Penang, Malaysia: Third World Network, 2002.

Sandrasagra, Mithre J. "Globalisation Heightening Gender Inequalities." Third World Network, October 10, 2000.

Shiva, V., Jafri, A. H., Emani, A., Pande, M. Seeds of suicide: the ecological and human costs of globalisation of agriculture. New Delhi: Research Foundation for Science, Technology and Ecology, 2000.

Shiva, Vandana. "The effects of WTO on women's rights."

Smith, Reid Sanya. "Intellectual Property in Free Trade Agreements." UNDP Regional Trade Workshop - Doha and Beyond: Incorporating Human Development into Trade Negotiations. Colombo, Sri Lanka: UNDP Regional Centre in Colombo; UNDP Malaysia; Third World Network, 2007.

Smith, Sally, and Stephanie Barrientos, Catherine Dolan, Karin Kleinbooi, Chosani Njobvu, Maggie Opondo, Anne Tallontire Diana Auret. Ethical Trade in African Horticulture:

Gender, Rights and Participation . Brighton: Institute of Development, 2004.

Stone, Glenn Davis. "Biotechnology and Suicide in India." Anthropology, May 2002.

Tan, Celine. "No Additionality, New Conditionality: A Critique of the World Bank's Climate investment funds." Third World Network, May 2008.

Third World Network. "Trade: Doha Round will not prevent another food crisis." SouthNorth Development Monitor, December 19, 2008.

Tsikata, Dzodzi. "Globalisation the Cause of Poor Women's Woes, says panel." Third World Network, September 12, 1995.

United Nations Conference on Trade and Development. "Trade, Sustainable Development and Gender." Papers Prepared in Support of the Themes Discussed at the UNCTAD X Expert Workshop on Trade, Sustainable Development and Gender. New York \& Geneva: United Nations, 1999. 